\title{
Square Millimeter
}

National Cancer Institute

\section{Source}

National Cancer Institute. Square Millimeter. NCI Thesaurus. Code C65104.

A unit of area measurement equal to a square measuring one millimeter on each side.

One square millimeter is equal to $10(\mathrm{E}-2)$ square centimeter and $10(\mathrm{E}-6)$ square meter. 